\title{
Realizing rights within the Israeli Asylum Regime: a case study among Eritrean refugees in Tel Aviv
}

DOI:

10.1080/19376812.2017.1354309

\section{Document Version}

Accepted author manuscript

Link to publication record in Manchester Research Explorer

\section{Citation for published version (APA):}

Müller, T. R. (2018). Realizing rights within the Israeli Asylum Regime: a case study among Eritrean refugees in Tel Aviv. African Geographical Review, 37(2), 134-145. https://doi.org/10.1080/19376812.2017.1354309

\section{Published in:}

African Geographical Review

\section{Citing this paper}

Please note that where the full-text provided on Manchester Research Explorer is the Author Accepted Manuscript or Proof version this may differ from the final Published version. If citing, it is advised that you check and use the publisher's definitive version.

\section{General rights}

Copyright and moral rights for the publications made accessible in the Research Explorer are retained by the authors and/or other copyright owners and it is a condition of accessing publications that users recognise and abide by the legal requirements associated with these rights.

\section{Takedown policy}

If you believe that this document breaches copyright please refer to the University of Manchester's Takedown Procedures [http://man.ac.uk/04Y6Bo] or contact uml.scholarlycommunications@manchester.ac.uk providing relevant details, so we can investigate your claim.

\section{OPEN ACCESS}


Realizing rights within the Israeli Asylum Regime: a case study among

Eritrean refugees in Tel Aviv

\section{Tanja R. Müller, Global Development Institute, University of Manchester}

Abstract: Israel has since 2005 become an important destination for asylum seekers from sub-Saharan Africa. Even though it was an early signatory to the Convention Relating to the Status of Refugees, the development of an Israeli asylum regime has only gathered pace since then. That regime is underpinned by a discourse of securitisation that regards most asylum seekers as hostile 'infiltrators'. This paper is based on fieldwork among the Eritrean refugee community in Israel and in using two concrete case studies analyses the struggles of Eritrean refugees to realize rights and lay claim to a viable future. Their struggles provide insights into the wider debate on the lack of concrete footing of universal rights in actual political space.

\section{Keywords: refugees - universal rights - political space - Eritrea - Israel}

\section{INTRODUCTION}

One of the central problems of the $21^{\text {st }}$ century is the lack of solid footing of universal human rights in actual political space (Long 2011). This becomes particularly apparent when looking at important parameters of the contemporary global political economy that is characterised by the movement of people due to various forms of (forced) displacement. Yet, global policies on displacement and resulting entitlements are guided by conventions originally developed for a particular refugee population after World War II, a fact that raises questions whether those are fit for purpose in dealing with the complex patterns of displacement in the 21 st century. ${ }^{1}$ In fact, in the global order we find on the one 
hand increased movements of capital, technologies and of certain (elite) population groups; on the other hand surplus populations are being submerged into a system of humanitarian governance that lacks universal rights. We thus witness 'mutations in citizenship', where heterogeneous populations can claim diverse rights and have the means to meet a variety of needs, while others struggle to make rights-based claims or gain access to fundamental material needs. The sites of these 'mutations in citizenship' are 'spaces of assemblage', where rights or their denial emerge out of new forms of political mobilisation and associated claims in specific settings (Brun 2001; Ong 2006; Sassen 2008; Tsianos and Karakayali 2010).

Israel is a good example where those dynamics can be studied in relation to displaced populations who qualify for universal rights in line with relevant refugee conventions, but where those populations - or rather subgroups among them - find it almost impossible to realise many of those rights. This is partly due to the increasingly urban and individualised dimension of refugeehood and the fact that refugees and other categories of migrants in reality often use the same brokers, travel similar routes, and may come to live in the same communities (Crisp 2008; Van Hear 2011). This paper does not argue, as some have suggested, that definitions of who is a refugee need to be expanded to a variety of groups unable to meet basic needs in their place of origin (see for example Shacknove 1985). In contrast, it regards the general criteria of absence of state protection and well-founded fear of prosecution based on important characteristics at the core of one's identity that the relevant refugee conventions are built on as valid justifications for a global commitment to humanitarian principles and justice (Lister 2013). ${ }^{2}$ In turn, those suffering from a well-founded 
fear of prosecution have (in theory) the right to 'reasonable access to full membership in a society of refuge' (Lister 2013, 669), either temporarily or for the long-durée. In practice, however, as this paper will show, focusing on one specific subgroup of refugees in Israel, the Eritrean refugee population, this is often not the case and few mechanisms exist to enforce refugee entitlements. ${ }^{3}$ The paper will analyse the Israeli response to this first big influx of non-Jewish refugees into the country and how this response interacts with and contradicts claims to aspired rights of those refugees. It will ultimately argue that the trajectories of Eritrean refugees in Israel are paradigmatic for an international system that has no clear mechanism on how to deal with mobile, often urban, refugee populations if their country of refuge refuses to recognise refugee status determination (RSD) procedures.

The paper is structured as follows: The next section will provide some background to the influx of African refuges into Israel with a specific focus on refugees from Eritrea and discuss the Israeli asylum regime as it has evolved. Subsequently in the form of two detailed personal case studies paradigmatic for the life trajectories of Eritrean refugees in Israel, rights violations on their journey and in interactions with the changing patterns of the Israeli asylum regime are being discussed. The paper concludes with some reflections on the necessity to develop a global rights regime that can be enforced in practice.

\section{ERITREAN REFUGEES IN ISRAEL}

Israel has from 2005 onwards become an important destination for asylum seekers from Eritrea and other countries in sub-Saharan Africa who entered Israel through its southern border with Egypt/Sinai. These movements of people 
only came to a halt with the completion of a sophisticated border fence with state-of-the-art surveillance equipment in 2013 along the Egyptian border. ${ }^{4}$ In the years prior to the border fence completion, the number of African refugees residing in Israel had steadily increased. By September 2013, according to the Population and Immigration Authority, the African refugee population stood at 53,646, among them 35,987 Eritreans and 13,249 Sudanese. The majority live in southern Tel Aviv around the central bus station, where some neighbourhoods have been transformed, visible in cafés, bars, shops and hairdressing salons.

As indicated above, the largest group of those who came to Israel are Eritreans. In order to understand the wider context behind the arrival of Eritrean refugees in particular, a brief look at recent political developments within Eritrea is in order. Eritrea became Africa's newest nation state in 1993 after thirty years of armed struggle against Ethiopian rule. A decisive factor in achieving independence has been a strong sense of unity, extending to the considerable diaspora communities and constituting a prime example of transnationalism strengthening national belonging (Hepner 2009; Iyob 1997a; Müller 2012; Pool 2001). In the first decade after independence this has translated into a high propensity to forgo individual aspirations and contribute to the development of the country (Iyob 1997b; Müller 2004). Partly triggered by renewed conflict with Ethiopia in 19982000 that has put a hold to the implementation of a new constitution that would have guaranteed social and political rights, the Eritrean polity has become highly authoritarian, characterized by the crackdown on any form of dissent, the imprisonment of large numbers of people, and potentially indefinite military conscription for those under 40 years of age (Article ${ }^{19}$ 2012; Bundegaard 2004; Home Office 2012; Human Rights Watch 2009; Müller 2008; Reid 2005; 2009). 
Taken together, Eritrea can be regarded as a minimally legitimate state where large groups of individuals have a well-founded fear of prosecution (as stipulated explicitly by the OAU Convention). Those dynamics made Eritrea one of the largest producers of refugees in the world, with Israel having become the third largest recipient of Eritrean refugees worldwide (UNHCR 2010).

The people fleeing Eritrea are predominately young men who have been brought up with the promises of a post-liberation society enshrined in a progressive constitution. What made them leave Eritrea is the fact that the constitution's rights have been denied, while its obligations have been enforced through a militarized government (Müller 2008; 2012).

One reason Eritreans have come to Israel is because the country is perceived as a law-abiding democracy, a place where it is expected that the rights denied in Eritrea will be upheld. In addition there is an acute awareness among many refugees that the contemporary state of Israel was founded by refugees. There is thus a strong belief that Israel out of all places will honour the suffering of those who have been made refugees, and some of the Israeli civil society organisations that assist refugees explicitly refer to the legacy of refugeehood among the Jewish people. But looking at the wider response of the Israeli state to the arrival of Eritrean and most other African refugees shows a reality that largely fails to acknowledge any common bond created by the refugee experience.

Once Eritrean (and all other) refugees crossed Israel's southern border with Sinai they gave themselves up to Israeli army patrols and were subsequently taken to detention facilities run by the Israeli Prison Services, in most cases Saharonim Detention Centre near the border with Egypt. Saharonim began operations in 2007 and is a dedicated immigration detention facility with a total capacity of 
approximately 2,000 people. The amount of time refugees spent at Saharonim or other facilities could range from a few days to many months, depending on how many people arrived at any one time and other capacity issues on the Israeli side. Subsequently refugees were put on buses either to Beer Sheva, the nearest town, or Tel Aviv and were released into Israel without any further government support or guidance and without any of the entitlements the Israeli welfare state offers to its citizens (Furst-Nichols and Jacobsen 2011; Müller 2012; Paley 2011)

When the first refugees arrived the United Nations High Commissioner for Refugees (UNHCR) office was in charge of RSD but in 2009 the Israeli government assumed control via the newly established RSD Unit within the Authority of Immigration at the Office of the Interior. Acquiring official refugee status and subsequently citizenship rights is almost impossible though for nonJews due to the specific stipulations of Israeli citizenship law (see KritzmanAmir 2010, for a detailed discussion), and within government discourse and much of the media African refugees are in fact regarded as 'infiltrators', a term used to refer to enemies of Israel who are illegally entering the country (Ziegler 2011). This has resulted in repeated demonstrations against the African population groups in southern Tel Aviv by different sections of Israeli society, demonstrations that in spring 2012 were accompanied by violence against a number of African people and businesses (for an overview see Hebrew Immigrant Aid Society 2012; Tsurkov 2012).

More generally, in spite of having ratified the 1951 Convention in 1954, and accepted its protocols in 1968, Israel has not incorporated the convention into its domestic law, mostly because few non-Jewish refugees have previously arrived. 
The Israeli asylum regime in terms of legal underpinnings as well as its practices has thus been evolving in response to the increasing numbers of refugees from Africa (Kritzman and Berman 2009; Kritzman-Amir 2010; Paz 2011). ${ }^{5}$

This has resulted in a state of affairs where refugees are treated differently depending on their origin and time of arrival in Israel. The first Eritreans to arrive were given work permits partly in order to fill important gaps in the Israeli labour market that had come about in the wake of the second 'intifada' (Palestinian uprising) and a deportation of illegal migrants from Latin American countries (Kalir 2010; Kemp 2004; 2010; Yacobi 2008). ${ }^{6}$ All subsequent arrivals were given what is commonly called a Conditional Release Visa, the 2A5. The issuing of this visa is based on the UNHCR recommendation from 2008 to grant Eritreans temporary group protection as there is a general presumption that a majority are likely to satisfy the refugee convention definitions and suffer prosecution. The Conditional Release Visa thus allows refugees to remain in Israel temporarily as long as perilous conditions exist if returned either to Eritrea or to Egypt from where they entered Israel - but they can be deported once those conditions are judged to have changed. ${ }^{7}$ Conditional Release status also delays the start of official RSD and thus creates a 'ordered disorder' (Paz 2011) where refugees remain in a state of perpetual limbo and insecurity.

The Conditional Release Visa does not allow the right to work but working is tolerated unofficially and was confirmed as a quasi-official right by a court ruling in July 2010 since otherwise refugees would have no means to sustain themselves and the Israeli government would be faced with a humanitarian crisis (ARDC 2011; Ziegler 2011). Since November 2010, however, the sentence 'this is not a work permit' has been explicitly printed on the Conditional Release Visa 
making it harder for refugees to find work even though employers have been assured they will not be penalized for employing refugees (ARDC 2011). In parallel, the construction of a permanent detention facility to potentially house up to 11,000 refugees, Holot detention centre - defined as an 'open' facility but in reality a prison-like institution - was completed in the Negev desert, and a new Amendment to the Prevention of Infiltration Law passed on 10 December 2013 allows to jail asylum seekers for one year in prison, followed by indefinite detention in 'open' facilities such as Holot. ${ }^{8}$ In parallel, the Israeli government has instigated a 'voluntary departure' procedure where refugees agreeing to leave are given a grant of reportedly US dollars 3,500 if they agree to be flown to Uganda as a third country, but their status there is far from clear. This procedure has been heavily critiqued by the UNHCR among others, not least because it cannot be considered that people act of their free will when facing the choice between de-facto imprisonment and being sent back to their home country where their life could be in danger (Lior 2014c).

Taken together, Eritreans in Israel find themselves thrown into a refugeeexistence characterised by two dynamics of denial of the fundamental rights that their status as potential refugees, indirectly recognized by UNHCR through group protection procedures, should confer to them. Not only is a majority denied RSD procedures that could result in full protection as stipulated by the 1951 Convention. $^{9}$ At the same time, even the limited opportunities that came with group protection status and the temporary protection this entails in principle are being increasingly undermined by Israeli government policy. ${ }^{10}$

Those dynamics are further explored in detail in the following focusing on the stories of two Eritrean refugees in Tel Aviv. The two cases come from interview 
and observation data collected during three visits to Tel Aviv, for ten days in June 2010, for 28 days in March/April 2011, and for 12 days in March/April 2012. In addition I followed up with some earlier informants during a visit to Tel Aviv in September 2013. I conducted 20 in-depth interviews with Eritrean refugees (16 men and 4 women), 12 extensive informal conversations and a number of key informant interviews with staff of the various civil society organizations working with refugees, namely the African Refugee Development Centre (ARDC), Physicians for Human Rights, the Refugee Law Clinic, and the Hotline for Migrant Workers. I also spent social time in two of the main bars that serve as a meeting point for Eritreans and in private settings with Eritreans. Selection of Eritrean participants was based on snowball sampling methods. Interviews were mostly conducted on a one-to-one basis with me in English, in some cases I employed an Eritrean interpreter who was recommended by staff at the ARDC. While not easily generalizable, I believe my data gives a valid snapshot of the condition the Eritrean refugee population in Tel Aviv find itself in, the common dynamics behind people's individual decisions to leave and the uncertainties that unite them as refugees.

The following two cases have been chosen because they show particularly well that being a refugee entails a specific condition that demands a political agenda to restore citizenship-like rights beyond the nation state.

\section{TAXI TO TEL AVIV - THE STORY OF HAILE ${ }^{11}$}

The first narrative is the story of Haile who arrived in Israel in 2007, thus was among the 2,000 Eritreans who were given a work permit. Haile was a student at Asmara University in Eritrea in 2001, when students for the first time protested 
against government orders for additional service and in consequence were sent to a desert-camp for punishment (for details see Müller 2008). In subsequent years this generation of students was regarded with suspicion by the government and were prime recruits into the Warsay Yekealo unlimited service campaign. ${ }^{12}$ Haile himself was sent to construction work in Zoba Debub, the southern zone of Eritrea. He says 'there could have been a lot of ways we could have helped our country [Eritrea] to develop with the education we got, but we were used for simple construction labour.' He continues to say:

It was a punishment for us and they tried to set an example for the university students after us, show them the consequences of contradicting the government. [...] It was against my mind, you spend 16 years in education to contribute to the development of your country, but for them [the government] being educated is being like an enemy, that is why we were punished, not for a short time, when I was three years in the army it was like thirty years for me.

With no end-date for his service in sight and the arguably 'forced labour' (Kibreab 2009) demanded from him as a constant threat, Haile fled to Ethiopia, 'it was not an easy task, you have to pass all the frontline, it means you can be shot and killed', he recalls. Like the majority of Eritreans who crossed into Ethiopia at the time he was taken to Shimelba refugee camp. Shimelba, he remembers,

is a very isolated place with a lot of mental pressure, pressure from Eritrean opposition groups, there are many [UNHCR guidelines do not allow political agitation in the camps but those rules cannot be enforced], especially for the university students it is a big problem, one opposition group tells you 'you are educated people, you have this responsibility, you have to think about your 
country', but we did not see anybody who opposes the government with a clear vision and you feel it is not secure in the camp.

He did not sympathize with any of the opposition groups 'personally for me I could not find anyone who could satisfy me $[\ldots]$ and I certainly became to hate politics, I simply wanted to be a free person.'

Haile thus felt it was not safe to stay in Shimelba and decided to leave, 'always when you flee your country it is normal to think about a place where you can get good protection, all decisions you take are risky, so you need to find the safest place possible, I felt this was Europe.' He thus continued to Sudan to go to Europe eventually, 'but unfortunately this was not possible at the time', as people captured in Libya had been sent back to their country of origin or other unsafe locations. ${ }^{13}$ Then he learned about the possibility of going to Israel, 'when I was at the university I read a lot about Israel, I knew it is a very democratic country in the Middle East, but at the same time I also knew it was very difficult to go there.' Now he heard there were smugglers who brought people to Israel, 'so I thought, let me try, if I reach Israel I am in a country with democratic values.' In Sudan 'my experience for two months was everybody is exploiting you [...] I preferred to be in Ethiopia in the camp, in Sudan everybody from the security onwards, even if you have only very little money you will have to give it to them $[\ldots]$ this was a very crazy experience for me'. He thus embarked on the journey to Israel with a group of Eritreans. At the time he had to pay US\$2,000 and he was among the first groups of African refugees to arrive in Israel. When they walked over the border and were met by soldiers of the Israeli Defence Forces he was amazed how well they were treated, 'how civilized'. The refugees stayed for two weeks at the soldiers' base and then 'they [the soldiers] simply 
drove us to the city [of Beer Sheva] and told us to go and get a taxi to Tel Aviv'. With a group of others they scraped US\$ 100 together and took that taxi, they did not know where to go and had no connections, 'but the taxi driver knew where the refugees are and simply drove us to Levinsky park'. Even though Haile was one of those who was given a work permit the first few years of his life in Israel were difficult, but he worked his way up from cleaning the streets to a proper job in a restaurant and managed to save enough money to eventually open a small business that at the time of the interview ran well, but as none of the businesses owned by refugees are given proper licences is also constantly under threat from Israeli authorities. ${ }^{14}$ When thinking about the future he has no intention to leave for a third country, partly because to do that he would need to go to the Eritrean embassy, pay an estimated amount of two percent tax for the years he has been outside Eritrea in order to get a passport, 'and for me I do not want that passport, why should I pay for this, for me, Israel is heaven, because I can work, no-one is affecting my life'. And while such a statement can be constructed as if he was in reality an economic migrant, this would be a wrong interpretation of his life trajectory and refugeehood. The underlying dynamic behind Haile's journey to Israel is grounded in a well-founded fear of prosecution in Eritrea because he belongs to a group of former students regarded as politically subversive by the government, coupled with the universal aspiration to be 'free'. He says:

In a country [Israel] we do not belong to we can ask for our rights, I can say what I think about the government, that it is not good, but in our country [Eritrea], the country we gave our blood for, we have no rights, and we are not 
allowed to ask for our rights [...] I want to have the same feeling [being able to ask for one's rights] tomorrow in my country.

THIS GENERATION IS A DEAD GENERATION - THE STORY OF MICHAEL

The second narrative is the story of Michael who was a relative newcomer to Israel at the time of the interview in March 2011, as he had only arrived in November $2010 .{ }^{15}$ Most of his immediate family were fighters with the Eritrean Peoples Liberation Front (EPLF) during the war for Eritrean independence and many still work for the government. He says about himself: 'I was very small when independence was achieved, so I remember very little, but everybody was expecting to get freedom, rights, a good future in your own land [...] but unfortunately that did not happen'. Michael finished his secondary schooling in one of the technical schools and scored high enough in his matriculation exam to be able to join the university. He was, however, not allowed to do so but was asked for three years of service first, something he felt very frustrated about, 'they [the political leadership] do not want the people to learn in order to develop their lives, develop their country, they clearly said we don't need scholarly education'. He thus went to Sawa [the military training camp for national service] as ordered and was subsequently employed on national service terms for the highway construction company responsible for building roads in different parts of the country. He says about his time there: 'Even though we were supposed to go to university they let us serve the country for another three years [...] this really upset me, I was a young person, I wanted to study [...] but instead I served there under a lot of oppressive administration.' He worked 
alongside older men who had been with the EPLF during the liberation war and the only future he could see was to become like them, being asked to serve the country continuously. After he visited a friend who lived near the border with Ethiopia, in Tsorona, he was subsequently being accused of planning to escape the country, 'and that was when I decided I really had to leave, because once they accuse you of something your life becomes hell'. His first attempt was to get to Ethiopia together with some friends, but they were caught, interrogated and imprisoned and later transferred to prison work on an agricultural site in Gash-Barka, in the western lowlands of Eritrea. As 'once you enter the prison and even if you are released you cannot get a future life at all any longer' Michael - together with a small group of fellow prisoners - made a second attempt and successfully managed to escape to Sudan this time. 'We knew Eritrea was no more our country, we had to go.' At the time he had no plans to come to Israel, 'the first thing I was dreaming about was how to get to Sudan, I considered Sudan heaven, because we were so oppressed we believed in any neighbouring country we can have a free life, that was all we wanted'. This was at the beginning of 2007 when many Eritreans escaped to Sudan 'just like a stream of water', and he ended up in Wad Sheriffey refugee camp where he was registered with the UNHCR and where 'we were kept just like animals'. He hoped to be able to leave for the US via some relatives there, but this attempt eventually failed. 'The only thing on my mind was going to school, eventually getting some higher education', so he would have gone anywhere to achieve that objective. Eventually he felt the best option was to go to Europe via Libya, 'but Libya was the hardest place to survive as a refugee', one could not work, one was hassled by the police and security forces all the time, and from 2009 
onwards when Italy and Libya struck an agreement on the repatriation of refugees who tried to make their way from Libya to Italy people like him were simply stuck, 'with no future to imagine at all'. This was when he decided to come to Israel:

We sat in the house and were chatting about the situation, we knew we cannot go back to our country, this was like death [...] so we thought that OK, maybe Israel is better, because at least we can have freedom, because Israel is a democracy, we know that this is a very disturbing region, but Israel is one of the democratic nations in the world.

Michael arrived in November 2010, he had to pay US\$ 2,500 for the journey, spent 15 days with the army in a camp to be processed and was then given a bus ticket to Tel Aviv. Like Haile he went to Levinsky Park where he was met by a distant relative. Having arrived only recently he was given the Conditional Release Visa with the no-work-stamp on it, something he finds very disturbing, even though he has found work with a good employer in a food processing business. Reflecting on the situation he finds himself in he says:

In Israel it is very complicated, all the time I find myself nowhere, I don't know where my compass is $[. .$.$] you cannot programme your life, if I want to$ start my education here, I don't know what will happen in the next months, will I still be allowed to be here, so I don't have any hope or ambition in Israel, basically my plan is to leave Israel and go somewhere to continue my education.

More generally Michael points out clearly that he is a refugee but in spite of that fact he is not given any rights he should be entitled to. 
I could have made my life in my country, because it is my country, they [the Eritrean government] made me to be a refugee, brought me a lot of humiliation, you know to be all the time a refugee, I feel like I am a beggar, I am falling on the shoulders of other societies, but those government people are the ones who created that situation [...] this generation [referring to his own generation] is a dead generation because deliberately the regime in Eritrea killed our mental status because they provided a hell place called Sawa where they intimidate people, where they torture people, where they teach hardship to people and we are traumatized from that situation $[\ldots]$ all the restrictions, for example if you are in your home, you don't feel like home, you are afraid, the police may come $[\ldots]$ that trauma is alive in the minds of Eritreans. Here all the time people ask me, are you trying to form an opposition group, but we are already opposers, when we left the country we became opposers, we were not leaving our country legally by the airport, we were just escaping, running.

\section{THE STRUGGLE TO CLAIM RIGHTS AS A REFUGEE}

The stories of Haile and Michael - as did the narratives of the other interviewees collected in the course of this research - show that the different dynamics behind finding themselves as self-defined refugees in Israel are grounded in a lack of political space to realise universal rights, within Eritrea as well as on various stages of their journey. For those spoken to in the course of this research, deciding to go to Israel was to an important degree based on a turned-out-to-be idealistic perception that countries in Europe to which Israel is seen to belong in this imagined geography respond to the plight of refugees in ways that guarantee their rights as human beings. Berhane put it this way: 'We came because we 
thought Israel was a good country, democratic, welcoming to refugees' while Asmeron says 'I knew it is democratic, there is humanity' ${ }^{16}$ The foremost request for Eritreans in Tel Aviv is thus to have the legitimacy of their status recognized, everything else, including a right to work in order to improve one's life, is seen to follow from there (see also Stephen and Schmautz 2011). The majority cannot understand why this recognition (or at least the instigation of RSD procedures) is not self-evident, not least when considering the often horrendous journeys they have endured, in particular those who have arrived more recently and have been victims of rape, torture and blackmailing in the Sinai desert as documented by the various organisations (Fishbein 2010; Hotline for Migrant Workers 2011; Physicians for Human Rights 2010; Van Reisen et al., 2012). ${ }^{17}$ When a five-men Eritrean committee was elected with the aim to be the public voice for Eritrean refugees in Israel in early 2011 one of the committee's first symbolic actions was to issue an official looking ID card with photograph and signature to every refugee that reads Eritrean Political Asylum Seeker in Israel.

The fact that the core demand for recognition of their refugeehood is not met by the Israeli government results in the continuation of a state-of-being where fundamental needs are difficult to meet and rights almost impossible to claim, including those connected to physical well-being and aspirations. In relation to well-being a common experience is depression and other psychological problems, ultimately rooted in the denial of a secure status. Yodit, who has developed a number of psychosomatic illnesses explains in this respect: 'Even if I work I am always afraid I might be fired, because my documents do not allow work, it disturbs me, it makes my whole life very stressful., ${ }^{18}$ And Robel, even 
though he is among those with a work permit and has an employer who understands his overall situation says: 'My life is just standing still, today and tomorrow it is the same, I just earn money, but there is no progress and as a human I would like to see a little bit of progress in my life, to see I can have a future. ${ }^{19}$ This last point that is strongly echoed in Michael's story narrated above, that a future in any meaningful way does not exist for Eritrean refugees in Tel Aviv, is arguably at the core of a fundamental negation of rights that reenforces refugeehood. What Mekonnen says is true for all interviewees: 'We went to Ethiopia, from Ethiopia to Sudan, and from Sudan finally to Israel, because in Ethiopia and Sudan we were not safe, but now we know the trip is not over, because they don't accept me here in Israel and I don't get the right I am supposed to get. ${ }^{20}$ And Asmeron has this to say: 'We need the Israeli government to understand our problem, that it is the problem of the refugee, and then if they think they cannot help us they should let us go somewhere else, we are kept hostage here, with no rights, with nothing. ${ }^{21}$ Taken together, the narratives of Eritreans in Tel Aviv that lay claim to be rightfully regarded as refugees offer important insights into the refugee-condition in the 21 st century.

\section{CONCLUSION}

Looking at the case of Eritrean refugees in Tel Aviv enforces the argument that being a refugee is a condition with a political core, brought about by a negation of fundamental rights in one's country of origin combined with a well-founded fear of prosecution and as such distinct from other patterns of transnational movements. As such, a moral and institutional obligation does exist in international law to provide refugees with reasonable access to the means to 
make a living in places where refuge is being sought. This does not necessarily need to translate into full citizenship rights and in fact the majority of those who were interviewed for this research expressed a strong desire to return to Eritrea once the political conditions changed, as ultimately they aspire to be able to realize their rights within their national community. Asmeron put it this way: 'If in the morning the government [in Eritrea] goes down, in the evening I will be back there, because the basis of your life is your homeland, even if you could live better outside in material terms.'

Recent scholarship has emphasized the relatively widespread transnational legal consciousness of refugees and has explored how this is being used as a rightsclaiming tool (Schwenken 2013). This consciousness is indeed found among leading protagonists of the Eritrean community in Tel Aviv, but within the conditions of the Israeli asylum regime there is limited scope to use this to great extent in actual rights-based claims. On the other hand, the African refugee populations exercise agency, or engage in what Isin (2008) calls acts of citizenship, acting in a way as if certain rights had actually been granted, such as the right to work and welfare, within the parameters of available political space in Israel. Refugee populations find work and have mobilized some of their employers to support their protests. Others have opened businesses and through these engage in support networks for those less fortunate. Together with rightsbased and/or welfare oriented Israeli and international civil society organisations specific refugee populations can lay claim to a number of social services and in doing so contest their status as 'infiltrators' and arguably redefine social (if not political) membership within Israeli society (Hellgren 2013). But the recent detention policies at the same time show the limitations of such strategies in 
terms of realizing rights claims. As long as - in a highly decentralized manner - it is up to individual nations how global rights are being granted or denied and no formal mechanisms for responsibility sharing emerge, mobilisation practices around rights by refugee activists, local and international civil society actors and even organisations such as the UNHCR will continue to have limited influence (Fitzpatrick 2000). For individual refugees this can mean a stark choice. Samuel for example who is not only a community organiser but has been successful in running a business and obtaining a scholarship to study, and as such can be seen at the forefront of those who expanded social membership within Israeli society, becomes increasingly depressed. Faced with the choice of a potential future deportation order or a ticket to Uganda he says: 'I will not go to Uganda, what for, and also not to prison, I will rather return to Eritrea and see what happens, and if they kill me there at least my odyssey has come to an end. ${ }^{, 22}$

\section{ENDNOTES}

${ }^{1}$ The major international instruments concerning refugees are the United Nations Convention relating to the status of refugees, done 28 July 1951 (hereafter 1951 Convention), the Statute of the Office of the United Nations High Commissioner for Refugees, adopted 14 December 1950, and the United Nations Protocol relating to the Status of Refugees, done 31 January 1967. The then Organisation of African Unity (now African Union) adopted an additional Convention Governing the Specific Aspects of Refugee Problems in Africa (hereafter OAU Convention) on 10 September 1969 (entered into force 20 June 1974); it challenges the notion that prosecution is the essential criterion of refugeehood but uses the broader understanding of the minimally legitimate state and thus 
regards prosecution as only one manifestation of a lack of state protection of basic rights of its citizens.

${ }^{2}$ In the 1951 Convention's definition fear of prosecution that can form the basis for a valid asylum claim must not only be well-founded but based on a 'protected ground', the latter including race, religion, nationality, political opinion or membership in particular social groups - all markers of identities and in fact wide enough to include most forms of potential prosecution (see also Lister, 2013).

${ }^{3}$ A note on terminology is in order here: Legally speaking, Eritreans (and those of other nationalities) arrive in Israel as asylum seekers and becoming a legally recognised refugee would be the outcome of a successful asylum application. In this paper, however, the focus is on refugeehood as a condition of everyday life, not on legal categories and definitions, and thus the term refugee is being used when referring to Eritreans in Tel Aviv.

${ }^{4}$ The security fence covers the length of the 240 kilometres long border between Israel and Egypt and once completed had an immediate effect on the number of refugees entering the country: While in the first half of 2012 reportedly 9,570 citizens of various African countries entered Israel illegally, this number had been reduced to 34 in the first six months of 2013 and has since then stood at almost zero (Arutz Sheva, 2 July 2013, http://www.israelnationalnews.com/News/News.aspx/169521\#.UeXqBUB15DQ , accessed 25 March 2014, copy on file).

${ }^{5}$ Those dynamics are made possible by the fact that refugee protection adopts a universal human rights paradigm but the duties arising from it are in the 
jurisdiction of national governments (for a broader discussion see Fitzpatrick 2000).

${ }^{6}$ By mid 2011, 496 refugees from Darfur had received temporary resident permits (A5 visas), while 2000 Eritreans who had entered before 2009 had received B1 visas which permit holders to legally work in Israel (Paley 2011). Refugees from Darfur more generally are regarded as most deserving as the discourse around Darfur centres on the language of genocide, a concept that has a lot of resonance among Israeli politicians and the general public alike. For a detailed overview concerning the development of asylum procedures in Israel see Hotline for Migrant Workers (2012).

${ }^{7}$ This has happened with respect to refugees from South Sudan who were entitled to Conditional Release Visas in the past that the Israeli government revoked in the aftermath of the declaration of independence of the Republic of South Sudan in July 2011. In early 2012 the Israeli government announced it would detain and deport any South-Sudanese who did not leave voluntarily by 1 April 2012 because with independent statehood South Sudan was now considered a safe country to return to. This stipulation has been challenged by the Refugee Rights Clinic with a limited degree of success. Following a court ruling from 7 June 2012 temporary group protection of South Sudanese nationals came to an immediate end and on 17 June 2012 the first plane with 120 South Sudanese Nationals left Tel Aviv airport for Juba (Anat Ben-Dor, email communication 10 February 2012; ARDC and Hotline for Migrant Workers 2013; Fahamu Refugee Aid Legal Newsletter, 1 July 2012, http://www.refugeelegalaidinformation.org/fahamu-refugee-legal-aid-newsletter, accessed 24 March 2014, copy on file). 
${ }^{8}$ Holot is characterised as an 'open' facility because those brought there can in theory leave, but they need to check in three times a day and stay there at night. Holot's remote location in the Negev desert with the nearest town, Beer Sheva, about an hour away by bus makes this in fact a prison facility where occupants reportedly suffer from severe boredom. By February 2014, more than 400 refugees had already been arrested and transferred to Holot from their former places of residence, a policy that caused sustained big demonstrations by African refugees, civil society organisations, and employers of refugees combined for the first time but thus far with little effect in relation to a change in Israeli policy. In contrast, by March 2014 around 4000 detention orders had been issued to refugees all over Israel requiring them to report to Holot (Arad 2014; Berman 2014; Linthicum 2014; Lior 2014a; Lior 2014b; Margalit 2014; Tsurkov 2013). ${ }^{9}$ In the course of 2012 RSD interviews with some asylum seekers from Eritrea and Sudan finally began. By January 2014, reportedly 250 out of 1800 requests from both those nationalities had been examined. 150 requests were rejected, 2 Eritreans were granted refugee status and the rest remained undecided (Lior 2014d).

${ }^{10}$ On temporary protection dynamics and inherent obligations see Fitzpatrick (2000).

${ }^{11}$ All names are changed for reasons of confidentiality and other markers that would have made it possible to trace the interviewees in question have been removed. The recollection of Haile's story is based on an interview conducted March 31, 2011 in Tel Aviv. 'Haile' is male, 30 years old and from Adi Keih. ${ }^{12}$ A nationwide national service campaign was introduced in Eritrea in 1995, requiring all women and men between 18 and 40 years of age to undergo six 
months military training followed by twelve months civilian reconstruction activities as a citizenship obligation. At the time of its introduction the campaign was widely accepted. Under the so-called Warsay-Yekealo Development Campaign inaugurated in 2002 national service does not end after the stipulated 18 months but conscripts are made to stay in service indefinitely. They are mostly given civilian labour tasks often on army-owned construction or agricultural projects but are still under military command. The indefinite duration and treatment patterns have been described as a contemporary example of forced labour that contravenes international law (see Kibreab 2009).

${ }^{13}$ It is difficult to obtain strong evidence about what happens to Eritreans who are returned, but various incidences of imprisonment and torture have been reported (see for example Human Rights Watch 2009).

In addition, those who left Eritrea illegally and need consular services abroad are forced not only to pay a lump-sum of backdated two-percent diaspora tax payments, but at the same time need to sign a 'confession' that they have betrayed the country with their leaving and would accept any government punishment metered out to them should they ever return.

${ }^{14}$ Like for all refugees who run businesses his business is officially illegal, as even with all required payments no refugee has thus far secured an official business licence. In practice, however, most business owners are left alone and are not being bothered by the authorities, even though I am aware of some cases when fines had to be paid and closure was threatened. In spring 2012, during violent protests against 'infiltrators' in south Tel Aviv, police raided a number of refugee-owned restaurants and shops and destroyed food and stocks. 
15 'Michael' is male, 26 years old and from Dekemhare. The interview was conducted 31 March 2011 in Tel Aviv.

16 'Berhane' is male, 33 years old and from Mendefera. The interview was conducted 1 April 2014 in Tel Aviv. 'Asmeron' is male, 26 years old and from Tsorona. The interview was conducted 6 April 2011 in Tel Aviv.

${ }^{17}$ Among the people I encountered in the course of this study, one woman was raped in Sinai and had an abortion in Israel ('Luul', interviewed 17 April 2011 in Tel Aviv). One man whom I talked to during an informal conversation in Levinsky Park on 7 April 2011, told me about how he had been tortured and showed me torture wounds on his body. He had come to Israel six months before I met him and had visible scars on his arms and legs where he was chained. He had been held for 10 months by Bedouin smugglers and was only released after relatives abroad managed to send a payment of US\$11,000. Shahar Shoham from Physicians for Human Rights confirmed that ransom demands had shot up and that people held as hostages now often needed to pay as much as US\$ $15,000$.

18 'Yodit' is female, 25 years old and from Asmara. The interview was conducted 10 April 2011 in Tel Aviv.

19 'Robel' is male, 38 years old and from Asmara. The interview was conducted 14 April 2011 in Tel Aviv.

20 'Mekonnen' is male, 30 years old and from Senafe. The interview was conducted 30 March 2011 in Tel Aviv.

${ }^{21}$ The Israeli government has in the past been reluctant to consider reallocation applications to third countries and if so only on exceptional humanitarian grounds. I am personally aware of one family where one partner is Ethiopian and 
one Eritrean who were prosecuted on religious grounds in Eritrea who have been granted asylum in the United States and were allowed to leave after a long drawn out process. The Israeli side feared this would act as a magnet for a bigger refugee influx, an argument that with the new border fence should have become obsolete.

22 'Samuel' is male, 27 years old and from Senafe. This conversation took place on 15 September 2013 in Tel Aviv, a time when rumours about a deal between Israel and Uganda were already rife. 


\section{REFERENCES}

African Refugee Development Centre (ARDC). 2011. World Refugee Day Report. Tel Aviv: ARDC.

African Refugee Development Centre and Hotline for Migrant Workers. 2013. 'Do Not Send Us So We Can Become Refugees Again': From 'nationals of a hostile state' to deportees: South Sudanese in Israel. Tel Aviv: ARDC and Hotline for Migrant Workers.

Arad, R. "Israeli employers support African migrants' right to strike”. Haaretz, January 14, 2014.

Article 19. 2012. Eritrea: A Nation Silenced. London: ARTICLE 19.

Berman, L. "Week after ban, African migrants take part in Knesset meeting". Times of Israel, January 15, 2014.

Brun, C. 2001. "Reterritorializing the relationship between people and place in refugee studies”. Geografiska Annaler 83(B (1)): 15-25.

Bundegaard, C. 2004. "The Battalion State. Securitization and Nation Building in Eritrea". PSIS Occasional Paper 2, The Graduate Institute of International Studies, Geneva.

Crisp, J. 2008. "Beyond the nexus: UNHCR's evolving perspective on refugee protection and international migration". New Issues in Refugee Research, Paper no. 155.

Fishbein, E. 2010. "Desert Hell”. Yediot Ahronot, November 19. http://www.scribd.com/doc/45134410/Desert-Hell

Fitzpatrick, J. 2000. “Temporary Protection of Refugees: Elements of a Formalized Regime”. American Journal of International Law 94: 279306. 
Furst-Nichols, R. and K. Jacobsen. 2011. “African Migration to Israel. Debt, Employment and Remittances”. Boston, MA: Tufts University, Feinstein International Centre.

Hellgren, Z. 2013. "Negotiating the Boundaries of Social Membership: Undocumented Migrant Claims-making in Sweden and Spain”. Journal of Ethnic and Migration Studies. doi: 10.1080/1369183X.2013.858016 Hepner, T. R. 2009. “Seeking Asylum in a Transnational Social Field: New Refugees and Struggles for Autonomy and Human Rights”. In Biopolitics, Militarism and Development. Eritrea in the Twenty-First Century, eds. D. O'Kane and T. R. Hepner, pp. 115-133. New York: Berghahn Books.

Home Office. 2012. ERITREA: Country of Origin Information Report. London: Country of Origin Information Service.

Hotline for Migrant Workers. 2011. "The Dead of the Wilderness". Testimonies from Sinai Desert, 2010. Tel Aviv: Hotline for Migrant Workers.

Hotline for Migrant Workers. 2012. Until our hearts are completely hardened: Asylum Procedures in Israel. Tel Aviv: Hotline for Migrant Workers Human Rights Watch. 2009. Service for Life. State Repression and Indefinite Conscription in Eritrea. New York: Human Rights Watch.

Isin, E. F. (2008). “Theorizing Acts of Citizenship”. In Acts of Citizenship, eds. E. F. Isin and G. M. Nielsen, pp. 15-43. London: Zed Books.

Iyob, Ruth. 1997a. The Eritrean Struggle for Independence. Domination, Resistance, Nationalism 1941 - 1993. Cambridge: Cambridge University Press. 
Iyob, Ruth. 1997b. "The Eritrean Experiment: a Cautious Pragmatism?” The Journal of Modern African Studies 35(4): 647-673.

Kalir, B. 2010. Latino Migrants in the Jewish State. Undocumented Lives in Israel. Bloomington, Indiana: Indiana University Press.

Kemp, A. 2004. "Labour migration and racialisation: labour market mechanisms and labour migration control policies in Israel”. Social Identities 10(2): 267-292.

Kemp, A. 2010. "Reforming Policies on Foreign Workers in Israel”. OECD Social, Employment and Migration Working Papers (No. 103, 41 pages). Paris: OECD.

Kibreab, G. 2009. "Forced labour in Eritrea". The Journal of Modern African Studies 47(1): 41-72.

Kritzman, T. and Y. Berman. 2009. "Responsibility Sharing and the Rights of Refugees: The Case of Israel". ExpressO, 25 pages. http://works.bepress.com/tally_kritzman_amir/

Kritzman-Amir, T. 2010. ""Otherness" as the Underlying Principle in Israel's Asylum Regime”. Israel Law Review 42(3): 603-627.

Linthicum, K. "In Israel, African immigrants find no refuge", Los Angeles Times, March 26, 2014.

Lior, I. "Thousands of African migrants march on Tel Aviv embassies". Haaretz, January 6, 2014a.

Lior, I. "1,000 asylum seekers protest detention centre in Negev". Haaretz, February 18, 2014b.

Lior, I. "Israel secretly flying asylum seekers to Uganda". Haaretz, February 19, 2014c. 
Lior, I. “Two Eritreans granted refugee status in rare decision”. Haaretz, January $27,2014 d$.

Lister, M. 2013. "Who are Refugees?" Law and Philosophy 32: 645-671.

Long, K. 2011. "Refugees, repatriation and liberal citizenship". History of European Ideas 37: 232-241.

Margalit, R. 2014. "Israel's Asylum Seekers Go on Strike”. The New Yorker.

Müller, T. R. 2004. ""Now I am Free" - Education and Human Resource

Development in Eritrea: Contradictions in the Lives of Eritrean Women in Higher Education”. COMPARE 34(2): 215-229.

Müller, T. R. 2008. "Bare life and the developmental state: the militarization of higher education in Eritrea”. Journal of Modern African Studies 46(1): $111-131$

Müller, T. R. 2012. "From rebel governance to state consolidation - Dynamics of loyalty and the securitisation of the state in Eritrea". Geoforum 43(4): 793-803.

Ong, A. 2006. "Mutations in Citizenship". Theory, Culture \& Society 23(2-3): $499-531$

Paley, M. 2011. Surviving in Limbo. Lived Experiences among Sudanese and Eritrean Asylum Seekers in Israel. Tel Aviv: Aid Organisation for Refugees and Asylum Seekers in Israel.

Paz, Y. 2011. "Ordered disorder: African asylum seekers in Israel and discursive challenges to an emerging refugee regime”. UNHCR Policy Development and Evaluation Series, New Issues in Refugee Research, Research Paper No. 205, www.unhcr.org/4d7a26ba9.html 
Physicians for Human Rights. 2010. "Hostages, Torture, and Rape in the Sinai Desert: A PHR-Israel update about recently arriving asylum seekers”. http://www.phr.org.i1/default.asp?PageID=183\&ItemID=767

Pool, D. 2001. From Guerrillas to Government. The Eritrean People's Liberation Front. Oxford: James Currey.

Reid, R. 2005. "Caught in the headlights of history: Eritrea, the EPLF and the post-war nation-state". Journal of Modern African Studies 43(3): 467488.

Reid, R. 2009. "The Politics of Silence: Interpreting Stasis in Contemporary Eritrea”. Review of African Political Economy 36(120): 209-221.

Sassen, S. 2008. "Neither global nor national: novel assemblages of territory, authority and rights". Ethics \& Global Politics 1: 61-79.

Schwenken, H. 2013. ""The EU Should Talk to Germany". Transnational Legal Consciousness as a Rights Claiming Tool among Undocumented Migrants". International Migration 51(6): 132-145.

Shacknove, A. E. 1985. “Who Is a Refugee?” Ethics 95(2): 274-284.

Stephen, S. and M. Schmautz. 2011. The Self-Perceived Needs of Homeless African Refugees in Tel Aviv's Levinsky Park. Tel Aviv: African Refugees Development Centre.

Tsianos, V. and S. Karakayali. 2010. "Transnational Migration and the Emergence of the European Border Regime: An Ethnographic Analysis”. European Journal of Social Theory 13: 373-387.

Tsurkov, E. 2012. "Cancer in Our Body". On Racial Incitement, Discrimination and Hate Crimes against African Asylum Seekers in Israel. Tel Aviv: Hotline for Migrant Workers. 
Tsurkov, Elisabeth. (2014). "Knesset passes revised law for detention of African asylum seekers". Web-blog +972 .

United Nations High Commissioner for Refugees (UNHCR). 2010. “Asylum Levels and Trends in Industrialised Countries 2009: Statistical Overview of Asylum Applications Logged in Europe and Selected non-European Countries". Geneva: UNHCR.

Van Hear, N. 2012. "Forcing the Issue: Migration Crises and the Uneasy Dialogue between Refugee Research and Policy”. Journal of Refugee Studies 25(1): 2-24.

Van Reisen, M.; M. Estefenos and C. Rijken. 2012. Human Trafficking in Sinai: Refugees between Life and Death. Brussels/Tilburg: Europe External Policy Advisors.

Yacobi, H. 2008. "Irregular Migration to Israel: The Sociopolitical Perspective”. European University Institute, CARIM (Cooperation project on the social integration of immigrants, migration and the movement of persons) Analytic and Synthetic Notes, Irregular Migration Series, 2008/63, http://hdl.handle.net/1814/10108

Ziegler, R. 2011. “A Matter of Definition: On 'Infiltrators' and 'Asylum Seekers' in Israel”. http://www.idi.org.il/sites/english/ResearchAndPrograms/ConsititionalLa w/Pages/AMatterofDefinition.aspx 
